\title{
Acute lower limb ischemia secondary to diffuse peritonitis
}

\author{
Peter Bereka, Ivan Kopolovets ${ }^{\mathrm{a}, \mathrm{b}}$, Vladimir Sihotsky \\ ${ }^{a}$ Clinic of Vascular Surgery, Eastern Slovak Institute of Cardiovascular Diseases, Faculty of Medicine, P. J. Safarik University, \\ Košice, Slovak Republic \\ ${ }^{b}$ Department of Surgical Diseases, Medical Faculty, Uzhhorod National University, Uzhhorod, Ukraine
}

\section{ARTICLE INFO}

Article history:

Submitted: 19. 8. 2019

Accepted: 24. 10. 2019

Available online: 7. 7. 2020

\section{Klúčové slová:}

Dehydratácia

Peritonitída

Septický šok

Trombóza a embólia

\section{SÚHRN}

Úvod: Akútna ischémia dolných končatín je väčšinou spôsobená embóliou, trombózou a traumatickými zraneniami. Samostatnú skupinu tvoria pacienti so sekundárnou akútnou ischémiou končatín k inému základnému ochoreniu.

Prezentácia kazuistiky: $V$ tomto článku popisujeme kazuistiku 72-ročnej ženy, ktorá bola hospitalizovaná na Klinike cievnej chirurgie s akútnou ischémiou dolnej končatíny. Podla predchádzajúcej anamnézy jeden deň pred hospitalizáciou pacientka bola vyšetrená chirurgom pre bolest' brucha: bez príznakov peritonitídy. Bola realizovaná ultrazvuková diagnostika brucha, kde sa nevyskytol žiaden akútny nález; podla laboratorných testov boli zvýšené leukocyty na 18,2 × 10\%/. Nasledujúci deň pacientku doniesli na konzultáciu k cievnému chirurgovi kvôli bolesti a necitlivosti pravej dolnej končatiny. Vzhladom na bolest' brucha a zvýšený počet leukocytov bola vykonaná v urgentnom režime CT angiografia, na základe ktorej bolo diagnostikované pneumoperitoneum a akútny uzáver artérií pravej dolnej končatiny. Vykonaná simultanná emergentná operácia: trombektómia tepien dolných končatín a laparotómia, kde bola diagnostikovaná perforácia pylorusa, difúzna peritonitída. Bohužial' pacientka zomrela v dôsledku hemodynamického zhoršenia a rozvoja polyorganného zlyhania na základe septického šoku.

Záver: Táto kazuistika predstavuje vývoj akútnej ischémie pravej dolnej končatiny ako komplikácie difúznej peritonitídy. Septický šok spôsobil dehydratáciu pacientky, zhoršenie hemokoagulačných parametrov a rozvoj sekundárnej trombózy artérií pravej dolnej končatiny.

(c) 2020, ČKS.

\section{ABSTRACT}

Background: Acute lower limb ischemia is generally caused by embolism, thrombosis, and traumatic injuries. However, patients with acute limb ischemia secondary to other underlying disease constitute a separate group.

Case presentation: In this paper, we describe a case report of a 72-year-old woman, who was hospitalized with acute right lower limb ischemia to the Clinic of Vascular Surgery. According to past medical history, one day before hospitalization, the patient was examined by a surgeon for abdominal pain without signs of peritonitis. An abdominal ultrasound that did not reveal any pathology was performed; laboratory tests, that indicated an increase in white blood cell count to $18.2 \times 10^{\%} / \mathrm{L}$, were carried out. Next day, the patient consulted the vascular surgeon as she experienced severe right lower limb pain, numbness. Considering abdominal pain and elevated white blood cell count, there was performed emergency CT angiography that detected pneumoperitoneum and acute arterial occlusion of the right lower limb. There was performed concurrent emergency surgery: thrombectomy of the lower limb arteries and laparotomy that revealed gastrointestinal

Keywords:

Dehydration perforation, diffuse peritonitis. Unfortunately, the patient died due to hemodynamic deterioration and the development of multiple organ failure.

Conclusion: This case report represents the development of acute lower limb ischemia as a complication

Peritonitis

Septic shock

of acute diffuse peritonitis. Septic shock resulted in the patient's dehydration, impaired blood coagulation

Thrombosis and embolism 


\section{Introduction}

Acute lower limb ischemia remains one of the main problems for vascular surgeons. Despite the possibility of early revascularization of acute lower limb ischemia, amputation, and mortality rates are high. ${ }^{1}$ Embolism and thrombosis are considered as the most common causes of acute limb ischemia. ${ }^{2}$ According to literature, acute lower limb ischemia can be caused by vascular injury, aortic dissection, severe pancreatitis, peritonitis, intestinal obstruction, abdominal compartment syndrome, as well as dehydration. ${ }^{3-6}$ Besides, acute limb ischemia may develop as a manifestation of multiple comorbidities. At the terminal stages, multiple organ failure is accompanied by coagulopathy and immune dysfunction that results in intravascular coagulation, immunocompromitation, and thrombosis., ${ }^{7,8}$ Rapid recognition and treatment of acute lower limb ischemia in emergencies are critical to maximally reduce ischemia duration. Considering diverse causes of acute lower limb ischemia, clinical and diagnostic errors may result in a high price to the patient - amputation or even death. In this paper, we present a case report of secondary acute lower limb ischemia in a patient with peritonitis.

\section{Case presentation}

The patient with complaints of intermittent abdominal pain, predominantly in the epigastric region, was delivered by an ambulance to the emergency department of the hospital. She was examined by a surgeon who detected tenderness to palpation of the right hypochondrium and mesogastrium without signs of peritonitis. The following laboratory tests were carried out: red blood cells $(R B C)$ $4.69\left(10^{12} / \mathrm{L}\right)$, hemoglobin $(\mathrm{HGB})-133.00$ (g/L), white blood cells (WBC) - $18.5\left(10^{9} / \mathrm{L}\right)$; C-reactive protein (CRP) - 1.51 $\mathrm{mg} / \mathrm{L}$, bilirubin $12.0 \mathrm{nmol} / \mathrm{L}$. An abdominal ultrasound did not reveal free fluid, visualized in the abdominal cavity. After the examination, analgesics, diet, an outpatient observation by a gastroenterologist was recommended. Next day, approximately 15 hours after the prior admission, the patient was delivered by the ambulance again; she required the consultation with a vascular surgeon, as she experienced severe right lower limb pain, numbness. Physical examination revealed blood pressure of $90 / 58 \mathrm{~mm} \mathrm{Hg}$, the pulse of 95 bpm; bloating, flatulence, tenderness to palpation in the mesogastrium; cold right leg with sensory and motor impairment; warm left leg with preserved sensitivity and motility; no pulse in the right femoral artery; normal pulse in the left femoral artery.

Doppler ultrasonography of the lower limb arteries was performed: the right lower limb - there was no blood flow through the external iliac artery, the common femoral artery (hypoechoic occlusion), the superficial femoral artery, the popliteal artery, the anterior tibial artery, and the posterior tibial artery. The arteries of the left lower limb were passable, triphasic.

The following medical conclusion was made - Rutherford class IIb acute right lower limb ischemia, occlusion of the external iliac artery, the common femoral artery, the superficial femoral artery, the popliteal artery, the anteri- or tibial artery, and the posterior tibial artery. The patient was emergently hospitalized at the Clinic of Vascular Surgery. To exclude aortic dissection and other abdominal pathology, emergency CT angiography was performed. CT angiography findings: total occlusion of the common iliac artery and the external iliac artery $20 \mathrm{~mm}$ below the level of the aortic bifurcation (Fig. 1); the presence of intraperitoneal fluid; the signs of pneumoperitoneum within the abdominal cavity with air collections beneath the anterior abdominal wall predominantly in the epigastric and perihepatic regions that indicated gastrointestinal perforation (Fig. 2).

Laboratory finding were supplemented: WBC - 17.20 $\left(10^{9} / \mathrm{L}\right), \mathrm{RBC}-4.69\left(10^{12} / \mathrm{L}\right), \mathrm{Hgb}-133.00$ (g/L), hematocrit $(\mathrm{HMC})-40.20(\%)$, fibrinogen $-5.5(\mathrm{~g} / \mathrm{L})$, natrium $(\mathrm{Na})-$ $130.0(\mathrm{mmol} / \mathrm{L}), \mathrm{S}-c r e a t i n i n e-316.4(\mu \mathrm{mol} / \mathrm{L}), \mathrm{S}$-potassium - 4.3 (mmol/L), S-glucose - 8.6 ( $\mathrm{mmol} / \mathrm{L})$, serum glutamic-oxaloacetic transaminase (S-GOT) - 4.96 ( $\mu \mathrm{kat} / \mathrm{L})$, serum glutamic-alanin transaminase (S-ALT) - 3.03 ( $\mu$ kat/L), S-urea - 21.41 ( $\mathrm{mmol} / \mathrm{L})$.

An emergency simultaneous surgery was performed.

The first stage included thrombectomy of the common iliac artery, the external iliac artery, the common femoral artery, the superficial femoral artery, the popliteal artery

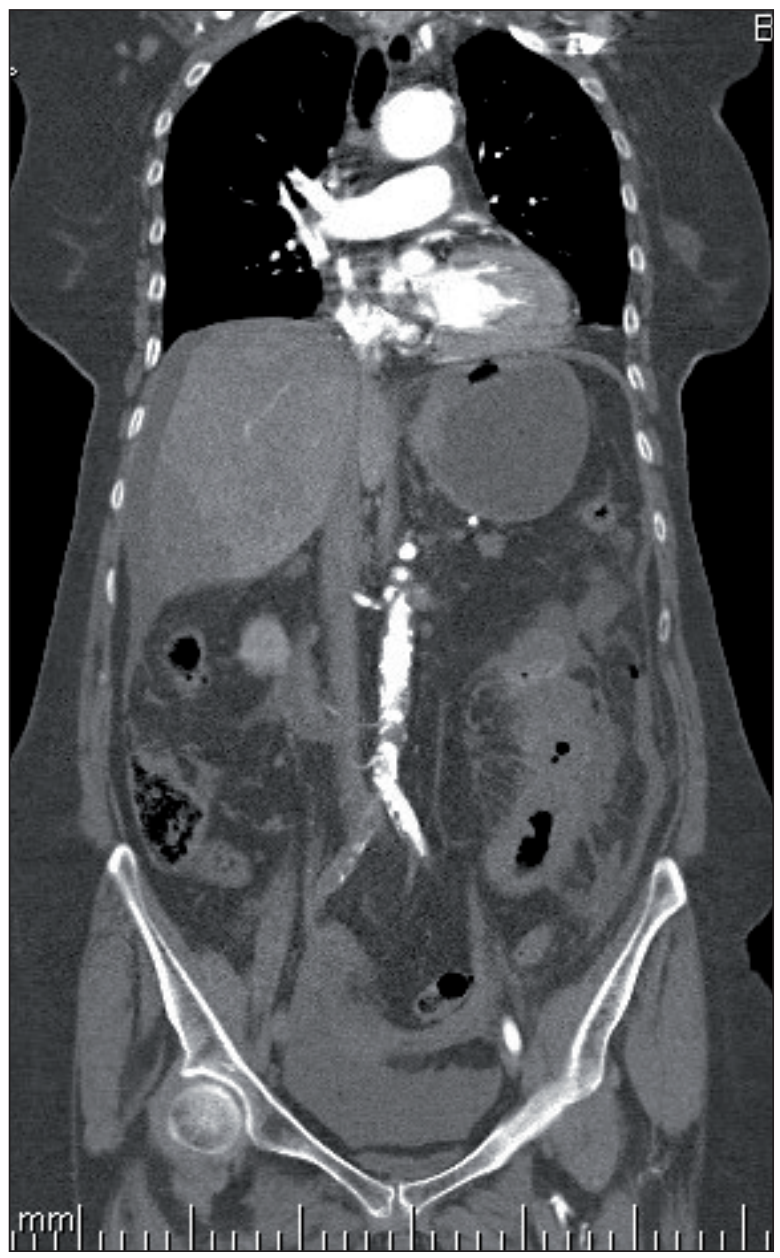

Fig. 1 - CT angiography of total occlusion of the common iliac artery and the external iliac artery $20 \mathrm{~mm}$ below the level of the aortic bifurcation. 


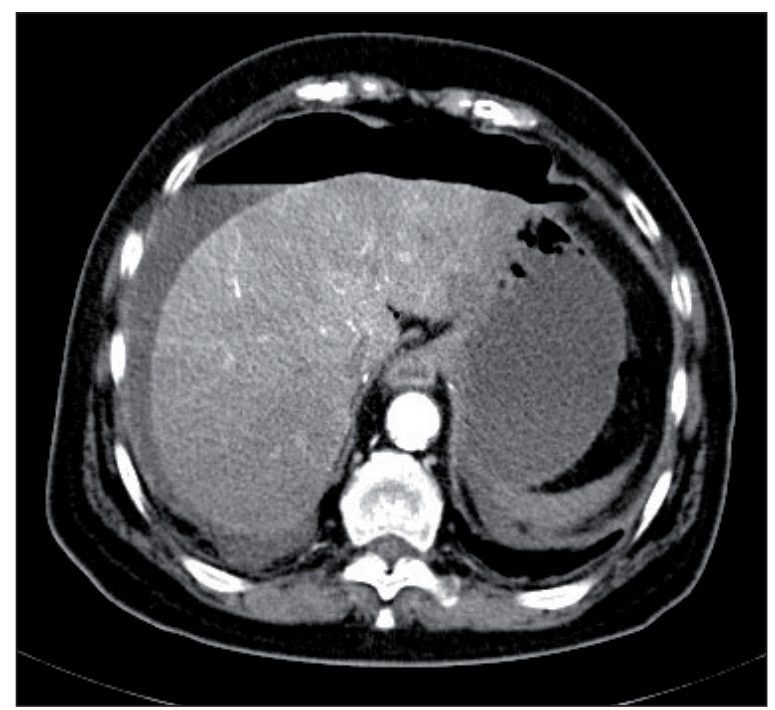

Fig. 2 - The presence of intraperitoneal fluid - the signs of pneumoperitoneum within the abdominal cavity with air collections beneath the anterior abdominal wall predominantly in the epigastric.

via femoral access using a Fogarty catheter under general anesthesia.

The second stage included midline laparotomy and revision of the abdominal cavity. After opening the abdominal cavity, the presence of a stinking smell and about $2,000 \mathrm{ml}$ of cloudy, foul-smelling fluid was observed. Surgical revision of the abdominal organs revealed a perforated peptic ulcer approximately $7 \mathrm{~mm}$ in size on the anterior wall of the pylorus. It was closed with three sutures; omentoplasty was performed. Surgery was followed by the reduction in blood pressure, bradycardia, asystole. Cardiopulmonary resuscitation and indirect cardiac massage were unsuccessful. The patient died.

An autopsy was performed.

The cause of death - peritoneal shock; the underlying disease - chronic perforated peptic ulcer; the main complication - diffuse fibrinous purulent peritonitis; concomitant diseases - embolism and right lower extremity deep vein thrombosis; shock-induced changes in the lungs and kidneys, venous stasis of the internal organs, cerebral and pulmonary edema

\section{Discussion}

Despite significant advances in treating vascular pathology, acute lower limb ischemia remains one of the greatest challenges in emergency vascular surgery. Any sudden impairment of the arterial flow to the limb results in ischemia, causing a potential threat to limb viability.2,9 Population aging increases the prevalence of acute lower limb ischemia. The main etiological factors of acute lower limb ischemia are arterial embolism and thrombosis of an atherosclerotic artery or a bypass graft. In $80 \%$ of the cases, embolism is of cardiac origin (atrial fibrillation). ${ }^{10}$ In embolism, an embolus tends to lodge in the area of arterial bifurcation, namely the bifurcation of the common iliac artery, the common femoral artery, the popliteal artery. In cancer patients, embolism may be caused by metastases. ${ }^{5}$ Primary thrombosis, as a cause of acute limb ischemia, is a complication of atherosclerotic stenosis of the artery. ${ }^{1}$ When taking a history from such patients, there are often detected clinical signs of atherosclerotic lower limb peripheral artery disease over the last period. ${ }^{11}$ The patients with acute limb ischemia secondary to other underlying disease constitute a separate group. ${ }^{8,12}$ In our case report, the patient presented with diffuse peritonitis being untimely diagnosed and complicated by acute arterial occlusion of the right lower limb. In case of severe endogenous intoxication, the cardiovascular system plays a critical role since the further course of the disease is determined by hemodynamic changes. ${ }^{13,14}$ Peritonitis, as a pathological process, can trigger thrombus formation due to the activation of the processes of hypovolemia, stress, pain, and adynamia. ${ }^{15}$ In acute diffuse peritonitis, 4-9 liters of fluid are lost that result in the development of hypovolemic or septic shock. ${ }^{16}$ Intestinal paralysis, vomiting, and fasting aggravate fluid deficiency. Clinical signs of septic shock include toxemia, tachycardia, oliguria, high-cardiac-output state, reduced vascular resistance, impaired function of the immune system and multiple organ failure. ${ }^{17} \mathrm{Hy}-$ poperfusion is accompanied by volume overload of the myocardium, a significant reduction in its contractibility, the elevated level of central venous pressure, and a gradual reduction in blood pressure. ${ }^{18,19}$

When analyzing the patient's condition during hospitalization, there were observed the classical signs of septic shock manifested themselves as dehydration, arterial hypotension $<90 \mathrm{~mm} \mathrm{Hg}$, tachycardia $>90 \mathrm{bpm}$, increased breathing rate $>20 / \mathrm{min}$, oliguria. Systemic injury to vascular endothelium results in the activation of blood coagulation factors. In the patients with acute diffuse peritonitis, defects in hemostasis manifest themselves as coagulation disorders, namely elevated plasma levels of fibrinogen and D-dimer, and reduced antithrombin III level. ${ }^{20}$ Similar changes in the indicators of hemostasis are typical of the inflammatory processes and indicate the activation of the coagulation cascade, pointing to the risk of developing both thrombosis and septic complications. ${ }^{21,22}$

When evaluating laboratory findings of the presented patient, the manifestations of septic shock, coagulopathy and multiple organ failure were observed. There was found an increase in WBC count to $18.50 \times 10^{9} / \mathrm{L}$; fibrinogen - $5.5 \mathrm{~g} / \mathrm{L}$; international normalised ratio (INR) - 1.68; creatinine - $316.4 \mu \mathrm{mol} / \mathrm{L}$; urea $-21.41 \mathrm{mmol} / \mathrm{L}$.

The activation of the kinin system activates the processes of nitric oxide formation that causes peripheral vasodilation and displacement of blood flow to the skin and muscles resulting in ischemia of the parenchymal organs, disseminated intravascular coagulation, "shock lung" and "shock kidney". 23

The examination of the patient's dead body confirmed the processes of developing "shock lung" and "shock kidney" as signs of septic shock in the patient with diffuse peritonitis. Diffuse peritonitis resulted in sepsis accompanied by circulatory disorders complicated by acute arterial occlusion of the lower limb. Metabolic disorders at the cellular level and multiple organ failure led to the patient's death in the intraoperative period. 
The presented case report is of practical importance for surgeons as:

firstly, when examining a patient with elevated WBC count for abdominal pain, even in the absence of peritonitis signs, the objective methods of examination, e.g., abdominal X-ray and abdominal CT, should be used with the aim of differential diagnosis;

secondly, in patients with acute lower limb ischemia, ischemia can result not only from embolism and thrombosis; therefore, during the examination, it is important to focus not only on the affected limb but to assess the general patient's condition, especially if the patient had any other complaints or underwent any other examinations within the last few days.

\section{Conclusions}

Acute lower limb ischemia may develop secondary to another disease as its complication. In the presented case report, secondary acute right lower limb ischemia developed secondary to diffuse peritonitis. The development of sepsis led to the patient's dehydration, impaired blood coagulation parameters, multiple organ failure, and secondary right lower extremity artery thrombosis.

\section{Competing interests}

The authors declare that they have no competing interests. All authors read and approved the final manuscript.

\section{Funding}

No institution provided financial support for the conduct of the research and/or preparation of the article.

\section{Authors' contributions}

PB revised the manuscript and was the consultant of the case report, IK participated in drafting the article and designed the paper, VS performed the surgery and provided the necessary photos.

\section{References}

1. Santistevan JR. Acute Limb Ischemia: An Emergency Medicine Approach. Emerg Med Clin North Am 2017;35:889-909.

2. McNally MM, Univers J. Acute Limb Ischemia. Surg Clin North Am 2018;98:1081-1096.

3. Abideen Z, Abbas SF, Farooq M, et al. Acute Abdominal Aorta Thrombosis and Ischemic Rhabdomyolysis Secondary to Severe Alcohol Intoxication. Cureus 2016;8:e905.

4. Thoreau B, Gouaillier-Vulcain F, Machet L. Acute Lower Limb Ischaemia and Diabetes in a Patient Treated with Anti-PD1 Monoclonal Antibody for Metastatic Melanoma. Acta Derm Venereol 2017;97:408-409.

5. Overton J, Nicklin A, Eleftheriou $P$, et al. Recurrent acute lower-limb ischemia with multiple organ infarctions secondary to acute myeloid leukaemia M1. Ann Vasc Surg 2012;26:1128. e1-1128.e5.

6. Savchenko AA, Borisov AG, Zdzitovetskiy DE, et al. Functional activity of neutrophils and hemostasis pattern in patients with acute destructive pancreatitis. Medical Immunology 2018;20:551-560.

7. Moreno Sánchez T, Caro Mateo F, Moreno Rodríguez F. Solution to case 24. Acute lower limb ischemia secondary to chronic intoxication due to ergotamine ingestion. Radiologia 2010;52:585-586.

8. Malo FC, Acar P, Lapie V, Bédard V. Acute lower limb ischaemia secondary to intestinal occlusion. BMJ Case Rep 2018;2018: bcr2016218580.

9. Vemulapalli S, Patel MR, Jones WS. Limb ischemia: cardiovascular diagnosis and management from head to toe. Curr Cardiol Rep 2015;17:611.

10. Gerhard-Herman MD, Gornik HL, Barrett C, et al. 2016 AHA/ ACC Guideline on the Management of Patients with Lower Extremity Peripheral Artery Disease: Executive Summary. Vasc Med 2017;22:1-43.

11. Tummala S, Scherbel D. Clinical Assessment of Peripheral Arterial Disease in the Office: What Do the Guidelines Say? Semin Intervent Radiol 2018;35:365-377.

12. Hinojosa CA, Anaya-Ayala JE, Bermudez-Serrato K, et al. Surgical Interventions for Organ and Limb Ischemia Associated With Primary and Secondary Antiphospholipid Antibody Syndrome With Arterial Involvement. Vasc Endovascular Surg 2017;51:550-554.

13. Zonneveld R, Molema G, Plötz FB. Measurement of functional and morphodynamic neutrophil phenotypes in systemic inflammation and sepsis. Crit Care 2016; 20:235.

14. Andreassen SM, Berg LC, Nielsen SS, et al. mRNA expression of genes involved in inflammation and haemostasis in equine fibroblast-like synoviocytes following exposure to lipopolysaccharide, fibrinogen and thrombin. BMC Vet Res 2015;11:141.

15. Vardon Bounes F, Mémier V, Marcaud M, et al. Platelet activation and prothrombotic properties in a mouse model of peritoneal sepsis. Sci Rep 2018;8:13536.

16. Sartelli M, Catena F, Abu-Zidan FM. Management of intraabdominal infections: recommendations by the WSES 2016 consensus conference. World J Emerg Surg 2017;12:22.

17. Lipinska-Gediga M. Sepsis and septic shock-is a microcirculation a main player? Anaesthesiol Intensive Ther 2016;48:261-265.

18. Čandik $P$, Rybár $D$, Depta $F$, et al. Relationship between dynamic expiratory time constant tau(edyn) and parameters of breathing cycle in pressure support ventilation mode. Physiol Res 2018;67:875-879.

19. Osborn TM. Severe Sepsis and Septic Shock Trials (ProCESS, ARISE, ProMISe): What is Optimal Resuscitation? Crit Care Clin 2017;33:323-344.

20. Hoppe B. Fibrinogen and factor XIII at the intersection of coagulation, fibrinolysis and inflammation. Thromb Haemost 2014;112:649-658.

21. Iba T, Gando S, Saitoh D, et al. Antithrombin supplementation and risk of bleeding in patients with sepsis-associated disseminated intravascular coagulation. Thromb Res 2016;145:46-50.

22. Yasuda N, Goto K, Ohchi Y, et al. The efficacy and safety of antithrombin and recombinant human thrombomodulin combination therapy in patients with severe sepsis and disseminated intravascular coagulation. J Crit Care 2016;36:29_ 34.

23. Olyvach AV. The basis of pathology. Second edition. Uzhhorod National University, 2003:612. 